\title{
Epidemiology of brown rot on two apple cultivars in an organic apple orchard
}

\author{
Holb, I.J. ${ }^{1} \&$ Gáll J. ${ }^{2}$ \\ ${ }^{1}$ Centre of Agricultural Sciences, Institute of Horticulture, University of Debrecen 138 Böszörményi St., 4032 \\ Debrecen, Hungary; ${ }^{2}$ Faculty of Economics and Business Administration, University of Debrecen
}

\begin{abstract}
Summary: In a two-year-study, the temporal development of brown rot (Monilinia fructigena) on fruits was analysed in an organic apple orchard on an early (Prima) and one late (Idared) maturing cultivars at Debrecen-Józsa in Hungary. Out of five mathematical functions (linear, exponential, three-parameter logistic, Gompertz, Bertalanffy-Mitscherlich), the three-parameter logistic function gave the best fit to brown rot incidence of all cultivars in both years. Disease progress started at the end of June for cv. Prima and at the end of July for cv. Idared, then disease increased continuously from 6-8 weeks up to harvest in all cultivars. Descriptive disease variates derived from the three-parameter logistic function were used to analyse disease progress. These were: $Y_{f}$, the final disease incidence; $Y_{55}$, fruit incidence at day 55; $Y_{95}$, fruit incidence at day $95 ; \beta$ and $\theta$, the relative and the absolute rate of disease progress, respectively; $T_{1.5}$, the time when disease incidence reaches $1.5 \% ; M$, the inflection point and $A U D P C$, area under disease progress curve. Descriptive disease variates were significantly different $(\mathrm{P}<0.05)$ for $\mathrm{cv}$. Prima compared to cv. Idared, except for the relative and absolute rate of disease increase, $\beta$ and $\theta$, respectively. The largest differences among cultivars were in the values of the AUDPC. Disease progress curves and descriptive disease variates were presented and the practical implications of the results were discussed.
\end{abstract}

Keywords: apple, brown rot, Monilinia fructigena, fruit rot, descriptive disease variates, epidemiology, logistic function, organic apple

\section{Introduction}

Monilinia fructigena (Aderh. \& Ruhl.) Honey is an important pathogen causing pre- and post-harvest fruit rot in apple orchards. Losses caused by M. fructigena are usually low in well-treated conventional and integrated apple orchards (Moore, 1950; Byrde and Willetts, 1977; Berrie, 1989; Falconi \& Mendgen, 1994; van Leeuwen et al., 2000; Xu \& Robinson, 2000). Moore (1950) recorded an average of about $9 \%$ of apple fruits becoming infected with $M$. fructigena during the growing season in conventional apple orchards. In a seven-year study, Berrie (1989) reported mean post-harvest losses in cultivar (cv.) Cox's Orange Pippin that ranged from $0.1 \%$ to $0.6 \%$ in integrated apple orchards. Van Leeuwen et al. (2000) demonstrated that pre-harvest disease incidence was 4.2-4.3 \% in cv. James Grieve in 1997 and 1998, in cv. Cox's Orange Pippin this was 4.4\% in 1997 and $2.7 \%$ in 1998. Post-harvest yield loss amounted on average $1.5-2.0 \%$ for both cultivars. In a similar study made in the UK, final brown rot incidence on apple fruits was ranging from 1 to $11 \%$ on cv. Cox's Orange Pippin in an integrated orchard without fungicide treatment (Xu et al., 2001). ). The latter two studies analysed the spatio-temporal development of $M$. fructigena up to harvest. Considerable yield loss was reported in unsprayed and poorly sprayed apple orchards. Burchill \& Edney (1972) assessed $36 \%$ fruit loss in unsprayed cider apple orchards. Holb (2003, 2004b) demonstrated that pre-harvest yield loss caused by $M$. fructigena ranged from 10 to $50 \%$ by harvest in Hungarian organic apple orchards, depending on the severity of fruit injuries. Holb (2003) demonstrated that temporal dynamics of brown rot development on cv. Elstar could be characterised by a power function in an organic orchard. However, no study has investigated the entire structure of the temporal dynamics of brown rot development and the effect of cultivar maturity time on disease development in organic apple production.

The objectives of this two-year study were firstly, to select the best mathematical function for describing temporal dynamics of brown rot development; secondly, to derive descriptive disease variates from the selected function in order to characterize disease progress. Analyses were made on an early and one late maturing apple cultivars in an organic apple orchard.

\section{Materials and Methods}

\section{Orchard site and plant material}

The study was made in an organic apple orchard at Mándok, Hungary. The orchard was planted with seven cultivars in 1997. Trees were on M.9 rootstocks and pruned to spindle shape. The orchard consisted of 80 rows, with a 
distance between rows of $4 \mathrm{~m}$ and within a row of $1.5 \mathrm{~m}$. The orchard was treated with approved fungicides and insecticides according to the Hungarian organic production guidelines (Anonymous, 1997). Selected cultivars for assessments were cvs. Prima and Idared. Harvest took place at the end of August for cv. Prima and at beginning of October for cv. Idared.

\section{Disease assessments}

Disease incidence of $M$. fructigena on fruits was assessed from 20 May until 30 August for cv. Prima and until 10 October for cv. Idared in 2011 and 2012. Assessments were made on a weekly basis in both years. Twenty trees of each cultivar, replicated four times, were selected for each assessment date. All diseased and healthy fruits on the trees were counted. Percentage of disease incidence of M. fructigena was calculated for each assessment date and cultivar. At each assessment date, data were averaged to give single values.

\section{Data analysis}

Disease incidence was plotted against time after the first assessment date (20 May). Linear, exponential, threeparameter logistic, Gompertz, Bertalanffy-Mitscherlich functions were tested for goodness-of-fit to the disease progress data. Models were fitted by maximum-likelihood through iterative nonlinear searching. The criteria for model evaluation were visual examination of observed values compared to fitted curves, the coefficient of determination $\left(R^{2}\right)$, mean square of the residuals (MSE), and visual examination of standardized residuals versus predicted values. We aimed to establish whether one function would give the best fit, overall, to the data of brown rot development.

According to preliminary analyses, the three-parameter logistic function gave the best fit to the disease progress data: $Y_{t}=Y_{f} / 1+\exp [-\beta(\mathrm{T}-\mathrm{M})]+\varepsilon_{t}$ in which $Y_{t}$ is an estimate for disease at time $t$ with random error $\varepsilon_{t}$, descriptive disease variates were derived from the fitted function: $Y_{f}$, the final disease incidence; $Y_{55}$, fruit incidence at day 55, seven weeks before the harvest of cv. Prima; $Y_{95}$, fruit incidence at day 95, seven weeks before the harvest; $\beta$, the relative apparent rate of disease progress; $\theta$, the absolute rate calculated as $Y_{f}^{*} \beta / 4 ; \mathrm{T}_{1.5}$, the time when disease incidence reaches $1.5 \%$; $M$, the inflection point, at which disease progress is fastest; $A U D P C$, area under disease progress curve, estimated with the midpoint rule for area estimation from 20 May until 30 August for cv. Prima and until 10 October for both cv. Idared.

Data of descriptive disease variates were subjected to analyses of variance (ANOVA) in order to test the difference of cultivars. Significant F-tests $(\mathrm{P}<0.05)$ were followed by a Least Significance Difference (LSD)-test for comparison of the means of descriptive disease variates using $\mathrm{LSD}_{0.05}$ values.

\section{Results and Discussion}

\section{Temporal dynamics of brown rot development}

The three-parameter logistic function provided an excellent fit to brown rot incidence of all cultivars in both years (Figure 1) as coefficients of determination were high $\left(\mathrm{R}^{2}>0.95\right)$ and mean square of residuals were low (MSE < 4) (Table 1). In cv. Prima, disease progress started at the end of June in both years. However, disease progress started only at the end of July and the beginning of August for cv. Idared. Disease increased continuously from 6-8 weeks up to harvest in all cultivars, then levelling-off at asymptotic levels depending on the year and cultivar.
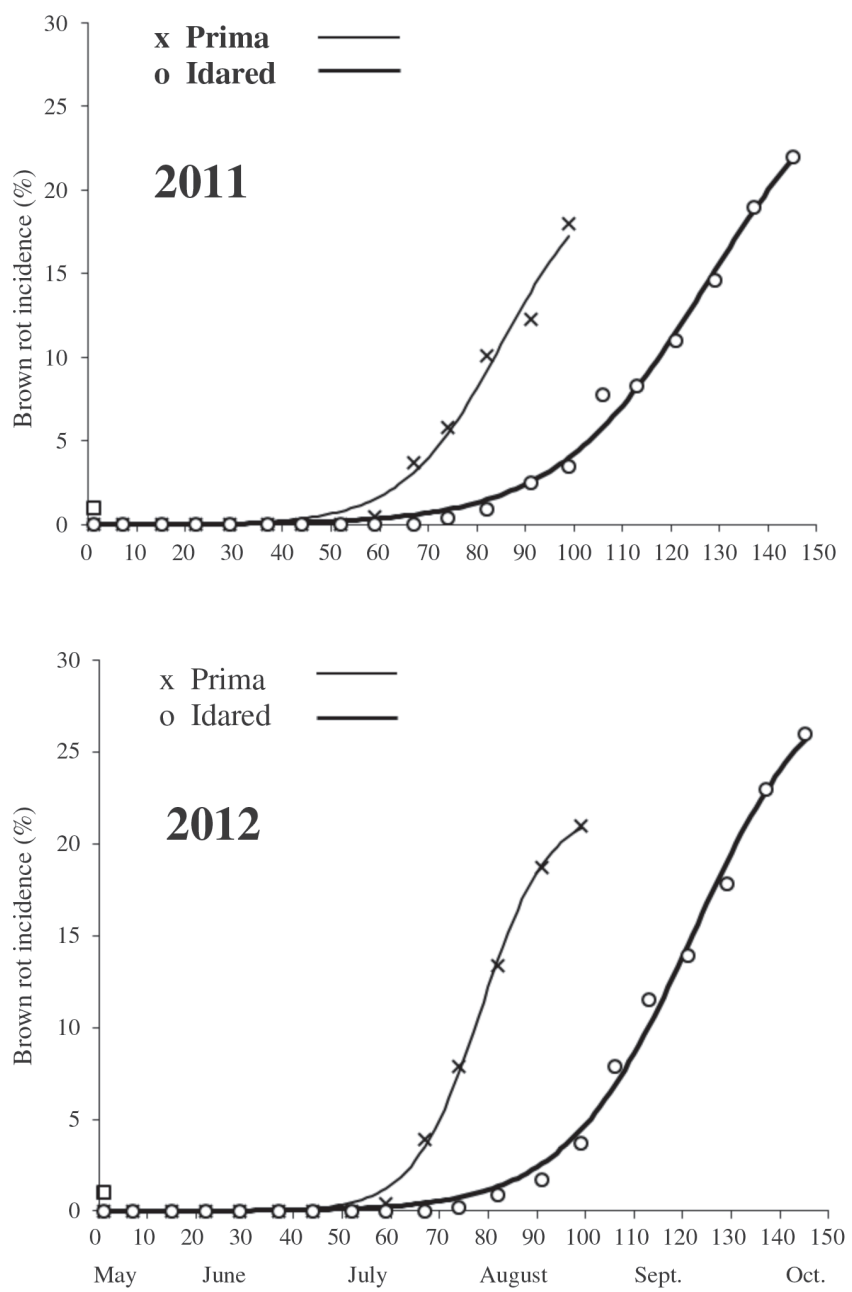

Figure 1 Disease progress curves of brown rot incidence caused by $M$. fructigena assessed on three apple cultivars (Prima, $\mathrm{x}$ and Idared, o) in an organic apple orchard (2011-2012, Mándok, Hungary). Points represent mean values and smooth lines are the fitted curves of logistic regression.

\section{Descriptive disease variates}

Values of descriptive disease parameters were significantly different $(\mathrm{P}<0.05)$ for $\mathrm{cv}$. Prima compared to cv. Idared, except for the relative and absolute rate of disease increase, $\beta$ and $\theta$, respectively (Table 2 ). 
Table 1 Equation, coefficient of determination $\left(\mathrm{R}^{2}\right)$ and mean square of residuals (MSE) for the three-parameter logistic function describing brown rot development on fruits in three apple cultivars (2011-2012, Mándok, Hungary)

\begin{tabular}{|l|l|l|c|c|}
\hline Year & Cultivar & Equation & $\mathbf{R}^{\mathbf{2 a}}$ & $\mathbf{M S E}^{\mathbf{b}}$ \\
\hline \multirow{2}{*}{2011} & Prima & $Y t=21.7 / 1+\exp [-0.098(T-85.2)]$ & 98.3 & 3.14 \\
\cline { 2 - 5 } & Idared & $Y t=29.0 / 1+\exp [-0.064(T-127.5)]$ & 99.3 & 0.87 \\
\hline \multirow{2}{*}{2012} & Prima & $Y t=21.9 / 1+\exp [-0.144(T-78.5)]$ & 99.8 & 0.02 \\
\cline { 2 - 5 } & Idared & $Y t=30.1 / 1+\exp [-0.076(T-122.0)]$ & 98.3 & 3.31 \\
\hline
\end{tabular}

${ }^{\text {a }}$ Coefficients of determination

${ }^{\mathrm{b}}$ Mean square of residuals

The actual values of the time when disease incidence reached $1.5 \%\left(T_{1.5}\right)$ were between day 58.6 and 60.5 for cv. Prima and day 75.2 and 83.2 for cv. Idared (Table 2). Estimates of $Y_{f}$ (final disease incidence) were lower than 22 $\%$ for cv. Prima, however, for the late harvested cultivars it was about $30 \%$. Values of $Y_{55}$ (7 weeks before harvest of cv. Prima) were 1.1 and 0.7 for cv. Prima in 2011 and 2012, respectively, which clearly show the starting of the epidemic. However, values of $Y_{95}$ (7 weeks before harvest) ranged between 3.2 and 6.3 for cv. Idared in the two years. Values of $Y_{95}$ for cv. Prima were close to $Y_{f}$ in both years (15.7 and 21.7 in 2011, and 20.1 and 21.9 in 2012, respectively).

Table 2 Parameter estimates for the descriptive disease variates of the brown rot incidence curves for three apple cultivars (2011-2012, Mándok, Hungary)

\begin{tabular}{|l|l|rr|rr|r|}
\hline Year & Parameter $^{\mathrm{a}}$ & Prima & Idared & LSD $_{0.5}$ \\
\hline 2011 & $\mathrm{~T}_{1.5}$ & $58.61^{\mathrm{b}}$ & $\mathrm{a}^{\mathrm{c}}$ & 82.21 & $\mathrm{~b}$ & 8.94 \\
\hline & $\mathrm{Y}_{\mathrm{f}}$ & 21.72 & $\mathrm{a}$ & 29.03 & $\mathrm{~b}$ & 4.25 \\
\hline & $\mathrm{Y}_{55}$ & 1.08 & $\mathrm{a}$ & 0.28 & $\mathrm{~b}$ & 0.56 \\
\hline & $\mathrm{Y}_{95}$ & 15.71 & $\mathrm{a}$ & 3.22 & $\mathrm{~b}$ & 3.15 \\
\hline & $\beta$ & 0.09 & $\mathrm{a}$ & 0.06 & $\mathrm{~b}$ & 0.02 \\
\hline & $\theta$ & 0.53 & $\mathrm{a}$ & 0.46 & $\mathrm{~b}$ & 0.05 \\
\hline & $\mathrm{M}$ & 85.21 & $\mathrm{a}$ & 127.51 & $\mathrm{~b}$ & 12.92 \\
\hline & $\mathrm{AUDPC}$ & 360.23 & $\mathrm{a}$ & 646.54 & $\mathrm{~b}$ & 218.81 \\
\hline & $\mathrm{T}_{1.5}$ & 60.51 & $\mathrm{a}$ & 83.22 & $\mathrm{~b}$ & 10.15 \\
\hline & $\mathrm{Y}_{\mathrm{f}}$ & 21.92 & $\mathrm{a}$ & 30.12 & $\mathrm{~b}$ & 2.23 \\
\hline & $\mathrm{Y}_{55}$ & 0.72 & $\mathrm{a}$ & 0.18 & $\mathrm{~b}$ & 0.13 \\
\hline & $\mathrm{Y}_{95}$ & 20.12 & $\mathrm{a}$ & 3.38 & $\mathrm{~b}$ & 6.14 \\
\hline & $\beta$ & 0.14 & $\mathrm{a}$ & 0.07 & $\mathrm{~b}$ & 0.04 \\
\hline & $\theta$ & 0.79 & $\mathrm{a}$ & 0.57 & $\mathrm{~b}$ & 0.12 \\
\hline & $\mathrm{M}$ & 78.57 & $\mathrm{a}$ & 122.07 & $\mathrm{~b}$ & 15.54 \\
\hline & $\mathrm{AUDPC}$ & 468.12 & $\mathrm{a}$ & 769.92 & $\mathrm{~b}$ & 301.17 \\
\hline
\end{tabular}

${ }^{a} \mathrm{~T}_{1.5}$ is the time when disease incidence reaches $1.5 \%$ (day); $\mathrm{Y}_{\mathrm{f}}$ is the final disease incidence $(\%) ; \mathrm{Y}_{55}$ or $\mathrm{Y}_{95}$ is an estimate of fruit incidence on day 55 or $95(\%) ; \beta$ is the relative rate parameter $\left(\right.$ day $\left.^{-1}\right)$; $\theta$ is the 'absolute' rate parameter $\left(\beta \bullet \mathrm{Y}_{\mathrm{f}} / 4\right)\left(\%\right.$ day $\left.^{-1}\right) ; \mathrm{M}$ is the inflection point, measured in days; area under the disease progress curve (AUDPC) estimated directly from the data with the midpoint rule for area estimation (\%-days).

${ }^{\mathrm{b}}$ Mean values of four replicates.

${ }^{c}$ Mean values within rows followed by different letters are significantly different at $\mathrm{P}=0.05$.

The relative rate of disease increase, $\beta$ was significantly higher in cv. Prima compared to cv. Idared in both years (Table 2). Differences were smaller in the absolute rate of disease progress, $\theta$, between cultivars largely because of the effect of $Y_{f}$.
The estimates of the inflection point $(M)$ were influenced by the length of time before the upper asymptote is reached (Table 2). An earlier asymptote in disease progress of fruit incidence was present for cv. Prima in both years (Figure 1) with lower $M$ values (85.2 in 2011, 78.5 in 2012) compared to $\mathrm{cv}$. Idared (127.5 in 2011, 122 in 2012, respectively).

The largest differences can be seen in the values of area under disease progress curves $(A U D P C$ ) (Table 2). The estimates of the $A U D P C$ were generally low for cv. Prima, but AUDPC values were significantly higher $(\mathrm{P}<0.05)$ for $\mathrm{cv}$. Idared. The AUDPC was mainly influenced by the level of the upper asymptote denoted by final disease incidence and date of harvest (Table 2).

In this study, the dynamics of brown rot development were analysed using mathematical functions and derived disease variates. Brown rot incidence at harvest was between $21.7 \%$ and $31.3 \%$ (Figure 1 and Table 2), which was higher than in earlier studies in integrated and conventional apple orchards (Moore, 1950; Berrie, 1989; Leeuwen et al., 2000, 2002; Xu et al., 2001). The possible reasons are that firstly, less effective insecticides and fungicides are approved in organic orchards, secondly, due to the less effective pest control, more injured fruits are present in organic apple orchards compared to integrated and conventional apple orchards. The presence of injured fruit is known to increase pre-harvest incidence of brown rot on apple fruits and the role of the insects as wounding agents of a fruit has also been emphasized in earlier studies (Holb, 2003; Xu, et al., 2000). On the other hand, previous studies showed that pre-harvest brown rot incidence ranged from 30 to $60 \%$ in untreated and organic apple orchards (e.g. Burchill \& Edney, 1972; Holb, 2003, 2004ab), which was higher than the results of this study. The higher incidence values in the study of Burchill \& Edney (1972) were due to data assessment in an unsprayed orchard block, and counts of diseased fruit also on the orchard floor and not only on the tree in the study of Holb (2003).

In sum, the present study demonstrated that temporal dynamics of brown rot development were significantly different between the early and the late maturing apple cultivars in an organic orchard; however, further investigation is needed on other apple cultivars and under different agroclimatic conditions to support the results of this study.

\section{Acknowledgements}

This research was partly supported by grants of the Hungarian Scientific Research Fund (K78399) and the NKTH-OM-00227/2008 as well as by a János Bolyai Research Fellowship awarded to Imre J. Holb.

\section{References}

Anonymous (1997): Biotermékek Előállításának és Minősítésének Feltételrendszere. (Role Systems for Production and Qualification of Organic Products.) Guidelines for Organic Crop Production) Biokultúra Egyesület, Budapest. pp. 67. 
Berrie, A. M. (1989): Storage rots of apple and pear in South East England 1980-88: incidence and fungicide resistance. In: Gessler C. (ed): Integrated control of pome fruit diseases. IOBC Bulletin, Locarno, Switzerland, pp. 229-239.

Burchill, R. T. and Edney, K.L. (1972): An assessment of some new treatments for the control of rotting of stored apples. Ann. Appl. Biol. 72, 249-55.

Byrde, R. J. W. \& Willetts, H. J. (1977): The Brown Rot Fungi of Fruit: Their Biology and Control. Pergamon Press, Oxford, pp.171

Falconi, G. J. and Mendegen, D.H. (1994): Epiphytic fungi on apple leaves and their value for control of the post-harvest pathogens Botrytis cinerea, Monilinia fructigena and Penicillium expansum. J. Plant Dis. Prot. 101(1), 38-47.

Holb, I. J. (2003): Analyses of temporal dynamics of brown rot development on fruit in organic apple production. Int. J. Hort. Sci. 9(3-4), 97-100.

Holb, I. J. (2004a): Effect of acidity on growth rate and stroma formation of Monilia fructigena and M. polystroma isolates. Int. J. Hort. Sci. 10(1), 63-67.
Holb, I. J. (2004b): The brown rot fungi of fruit crops (Monilinia spp.) II. Important features of their epidemiology (Review). Int. J. Hort. Sci. 10(1), 17-35.

Moore, M. H. (1950): Brown rot of apples: fungicide trials and studies of the relative importance of different wound-agents. J. Hort. Sci. 25, 225-234.

Xu, X-M. and Robinson, J. D. (2000): Epidemiology of brown rot (Monilinia fructigena) on apple: infection of fruits by conidia. Plant Pathol. 49, 201-206.

Xu, X-M and Robinson, J. D., Berrie, A. M. and Harris, D. C. (2001): Spatio-temporal dynamics of brown rot (Monilinia fructigena) on apple and pear. Plant Pathol. 50, 569-578.

Van Leeuwen, G. C. M., Holb, I. J. and Jeger, M. J. (2002): Factors affecting mummification and sporulation of pome fruit infected by Monilinia fructigena in Dutch orchards. Plant Pathol. 51, 787-793.

Van Leeuwen, G. C. M., Stein, A., Holb, I. J. and Jeger, M. J. (2000): Yield loss caused by Monilia fructigena in Dutch orchards. Eur. J. Plant Pathol. 75, 534-432. 